ReVISTA de BIOLOGía TROPICAL

\title{
Early development of two tropical fishes (Perciformes: Sciaenidae) from the Pantanal of Mato Grosso, Brazil
}

Tátia Leika Taguti ${ }^{1,2,3}$, Andréa Bialetzki ${ }^{2,3}$, William Severi ${ }^{4}$, Angelo Antonio Agostinho ${ }^{2,3}$ \& Luciana Fugimoto Assakawa ${ }^{5}$

1. Laboratório de Ictioplâncton. Systema Naturae Consultoria Ambiental Ltda. Rua 55, Jardim Goiás, 74810-230, Goiânia, Goiás, Brazil; tatialt@gmail.com

2. Núcleo de Pesquisas em Limnologia, Ictiologia e Aquicultura (Nupélia)/Universidade Estadual de Maringá (UEM), Av. Colombo, 5790, 87020-900, Maringá, Paraná, Brazil; bialetzki@nupelia.uem.br, agostinhoaa@gmail.com

3. Pós-graduação em Ecologia de Ambientes Aquáticos Continentais (PEA)/Departamento de Biologia (DBI)/UEM.

4. Laboratório de Ictiologia, Departamento de Pesca e Aquicultura, Universidade Federal Rural de Pernambuco, Rua Dom Manoel de Medeiros, s/n, Dois Irmãos, 52191-900, Recife, Pernambuco, Brazil; wseveri@depaq.ufrpe.br

5. Laboratório de Ictioplâncton. Neotropical Consultoria e Assessoria Ambiental. Rua José Camacho, n 3069, Porto Velho, Rondônia, Brazil; lfassakawa@gmail.com

Received 01-XII-2014. C Corrected 20-VI-2015. Accepted 24-VII-2015.

\begin{abstract}
The early life history stages are inadequately known for most fishes of the Neotropical region. Thus, larvae and juveniles of the species Pachyurus bonariensis and Plagioscion ternetzi, two corvina species found in the Pantanal of Mato Grosso, Brazil, were described, assessing ontogenetic changes in their external morphology, pigmentation, fin development, morphometry and meristics. Fish were collected in Chacororé Bay, on the Cuiabá River, between March 2000 and March 2004. Eighty individuals of each species were analyzed, comprising 60 larvae and 20 juveniles. Pachyurus bonariensis larvae exhibited a mouth in a terminal position that became sub-terminal; large, well-pigmented, spherical eyes that became small and elliptical in postflexion; preopercular spines (two internal and four external); 23 to 27 myomeres; initially sparse pigmentation that intensified, mainly in the ventral region; and the following fin formation sequence and total number of spines and rays: caudal, dorsal (XI+29-32), anal (II+six), pelvic (I+five) and pectoral (15-17). In contrast, the larvae of $P$. ternetzi exhibited a terminal mouth; large, well-pigmented, spherical eyes that decreased in size during development; preopercular spines (three internal and four external); 23 to 26 myomeres; pigmentation that was initially sparse, became evident only in late postflexion stage, with the presence of some chromatophores on the top of the head; and the following fin formation sequence and total number of spines and rays: caudal, dorsal (XI+30-36), anal (II+six), pelvic (I+five) and pectoral (16-18). In relationship the morphometric variables, only the snout-anal fin length differed between the two species, being initially larger in P. ternetzi, whereas it only became larger in juvenile $P$. bonariensis after $34 \mathrm{~mm}$. Despite the difficulty of intraspecific identification among fish larvae collected in natural environments, the morphological and morphometric tools used in the present study were effective in separating the early stages of development of the two morphologically similar species that share the same environment for reproduction. Rev. Biol. Trop. 63 (4): 1105-1118. Epub 2015 December 01.
\end{abstract}

Key words: corvina, larvae, Pachyurus bonariensis, Plagioscion ternetzi, fish.

The family Sciaenidae comprises teleost fish that inhabit marine, brackish and freshwater, with about 270 species distributed among 70 genera (Nelson, 2006). A number of 18 species have been recorded in Brazilian river basins, encompassing four genera, which include three Pachypops, nine Pachyurus, one
Petilipinnis and five Plagioscion species (Cassati, 2003).

The sciaenids are known as croakers, corvina or curvina, and the species belonging to Plagioscion in particular represent an important and abundant fisheries resource in Brazilian continental waters (Braga \& Gomiero, 1997; 
Santos, Rocha, \& Fredou, 2010; Nascimento, Mello, Oliveira, Pereira, \& Mendes, 2011). The high abundance of Plagioscion species may in part be a consequence of their adopted reproductive strategy, including spawning in parcels throughout the year and producing small, rapidly developing, pelagic eggs (Nakatani et al., 2001).

Studies conducted in the Amazon River basin (Oliveira \& Ferreira, 2008) and in the Tocantins (Soares \& Teixeira, 2012), São Francisco (Melo \& Severi, 2010), Paraguay (A. Bialetzki, unpublished data 2010) and Paraná Rivers (Bialetzki, Nakatani, Sanches, Baumgartner, \& Gomes, 2005) have found that sciaenid larvae are among the most abundant larvae in the pelagic region. The larvae of the species belonging to this family can be differentiated from other species that occur in freshwater, including other Perciformes (Cichlidae), because they present a body shape that is usually similar to the adult, with a relatively higher head, lower caudal peduncle (forming something similar to a drop), short and roughly triangular intestine and spines in the cephalic region.

In the Pantanal of the state of Mato Grosso (Paraguay River basin), three species belonging to the family Sciaenidae are found: Pachyurus bonariensis Steindachner, 1879, Plagioscion ternetzi Boulenger, 1895, and Plagioscion squamosissimus (Heckel, 1840) (Britski, Silimon \& Lopes, 1999). The larvae and juveniles of Plagioscion squamosissimus were described by Nakatani, Baumgartner and Baumgartner (1997), while Severi (W. Severi, unpublished data, 1997) and Nakatani et al. (2001) briefly described the early development of $P$. ternetzi. However, no study has been carried out addressing the ontogeny of $P$. bonariensis. The co-occurrence of these species within the same environment further hinders their interspecific identification, given that although $P$. ternetzi and $P$. bonariensis larvae are easily distinguishable from the larvae of other species, they are morphologically similar to each other. Thus, the objectives of the study were to (i) describe the early ontogeny of Pachyurus bonariensis and Plagioscion ternetzi; (ii) analyze morphometric and meristic data on these species; and (iii) compare the early development of the two species to provide information to distinguish them.

\section{MATERIALS AND METHODS}

Study area: The Barão de Melgaço Pantanal is located in the Northeastern portion of the Mato Grosso Pantanal, encompassing the cities of Santo Antônio de Leverger and Barão de Melgaço (Mato Grosso State). The Pantanal exhibits an extensive floodplain drained by the Cuiabá River Basin, intersected by extensive mounds, and is characterized by the presence of several lakes, regionally known as bays (W. Severi, unpublished data, 1997), including Chacororé Bay on the left river bank (16030'61" S - 56²8'60” W).

Data collection and analysis: Samples were collected between March 2000 and March 2004, always at 16 and $22 \mathrm{pm}$, using a conicalcylindrical plankton net with a $0.5 \mathrm{~mm}$ mesh opening and a mouth area of $0.1104 \mathrm{~m}^{2}$. The plankton net was dragged on the subsurface of the water for 10 minutes. The samples were stored in polyethylene bottles and immediately fixed in $4 \%$ formaldehyde buffered with calcium carbonate.

The samples were sorted, and individuals were separated and identified in the laboratory using the developmental sequence technique proposed by Ahlstrom and Moser (1976). This technique consists of comparing the morphology of smaller individuals to a known juvenile form. After identification, the specimens were classified according to their degree of development (Ahlstrom, Butler, \& Sumida, 1976, modified by Nakatani et al., 2001) into larval (preflexion, flexion and postflexion) and juvenile periods. A total of 60 individuals from the larval period and 20 from the juvenile period were selected for each species. Each period was described based on the degree of development and on the occurrence of the main morphological events. The individuals that best represented 
these characteristics were illustrated using a lucid camera. The individuals used in this study are stored in the Ichthyology Collection of the Center for Research in Limnology, Ichthyology and Aquaculture (Núcleo de Pesquisas em Limnologia, Ictiologia e Aquicultura - Nupélia) of Maringá State University (Universidade Estadual de Maringá - UEM), Paraná, Brazil (NUP 17105 to NUP 17108-P. ternetzi; NUP 17109 to NUP 17111-P. bonariensis).

To characterize the early development of the two species, the individuals were measured using a stereomicroscope with an ocular micrometer (model GSWH 10X/22 Olympus) producing a resolution of 100 line pairs per millimeter. The following morphometric variables were obtained (Ahlstrom et al., 1976): standard length (SL), snout length ( $\mathrm{SnL})$, eye diameter (ED), jaw length (JL), head depth (HD), head length (HL), body depth (BD) and the length from the tip of the snout to origins of pectoral $(\mathrm{SnP})$, pelvic $(\mathrm{SnV})$, dorsal $(\mathrm{SnD})$ and anal (SnA) fins. For meristic characterization, the number of total and pre and postanal myomeres and the rays of the pectoral $(\mathrm{P})$, pelvic (V), dorsal (D) and anal (A) fins were counted whenever possible. The body shape was determined according to the categories proposed by Leis and Trnski (1989) which relate ED to HL, BD to SL, and HL to SL.

Morphological comparisons based on the shape of the eye, mouth position, pigmentation patterns and the sequence of formation of the fin rays, along with meristic measures (internal and external number of preopercular spines and the number of total preanal and postanal myomeres) were performed to distinguish the early development of the species.

Analysis of covariance (ANCOVA) was conducted to test the relationships between morphometric variables (response variables) and the standard and head lengths (covariables). The data were previously log-transformed, and a significance level of $\mathrm{p}<0.05$ was adopted. All measurements cited throughout the text are in reference to the standard length.

\section{RESULTS}

\section{Pachyurus bonariensis}

Larval period (Fig. 1A, Fig. 1B, Fig. 1C, Fig. 1D, Fig. 1E; Table 1): A total of 60 individuals with standard lengths ranging from 2.30 to $11.71 \mathrm{~mm}$ were analyzed. At this stage, the body exhibited a moderate depth (20.6 to 34.3 $\%$ ), and the head size ranged from small to large (19.0 to $38.4 \%$ ). The yolk was fully absorbed in early preflexion (approximately $2.80 \mathrm{~mm}$ ). The finfold was hyaline, surrounds the body dorsoventrally at the height of the anal opening and was completely absorbed at $8.86 \mathrm{~mm}$. The intestine was short and roughly triangular. However, elongation occurred in postflexion stage, and the anus opened after the middle of the body. The mouth changed from terminal to sub-terminal starting at $7.00 \mathrm{~mm}$, and the nostril became double at $8.29 \mathrm{~mm}$. The eyes were well pigmented and spherical, becoming elliptical at the postflexion stage, and they exhibited a diameter ranging from large to small (20.9 to $41.7 \%$ ). The opercle was fully formed at approximately $3.00 \mathrm{~mm}$, and spines preopercular (two internal and four external) appeared in flexion larvae. In preflexion larvae, the gas bladder was inflated and the notochord was uninflected, and both were visible in transparency. In the next stage, flexion occurred, and it became possible to observe the hypural bones and the onset of the lateral line. In postflexion, at approximately $9.71 \mathrm{~mm}$, scales appeared in the caudal peduncle region. The total number of myomeres ranged from 23 to 27 throughout larval development. However, there was a change in the number of pre- and postanal myomeres between the stages of development. The number of preanal myomeres increased from seven to nine in preflexion, from eight to 11 in flexion, and from 11 to 14 in postflexion. The number of postanal myomeres ranged from 15 to 17 in preflexion, 13 to 17 in flexion and 12 to 13 in postflexion (Table 1 ).

The variables snout length (20.9 to 36.3 $\%$ ), head depth (71.5\% to $108.0 \%$ ), snout-pectoral fin length ( $20.1 \%$ to $38.4 \%$ ), snout-dorsal 

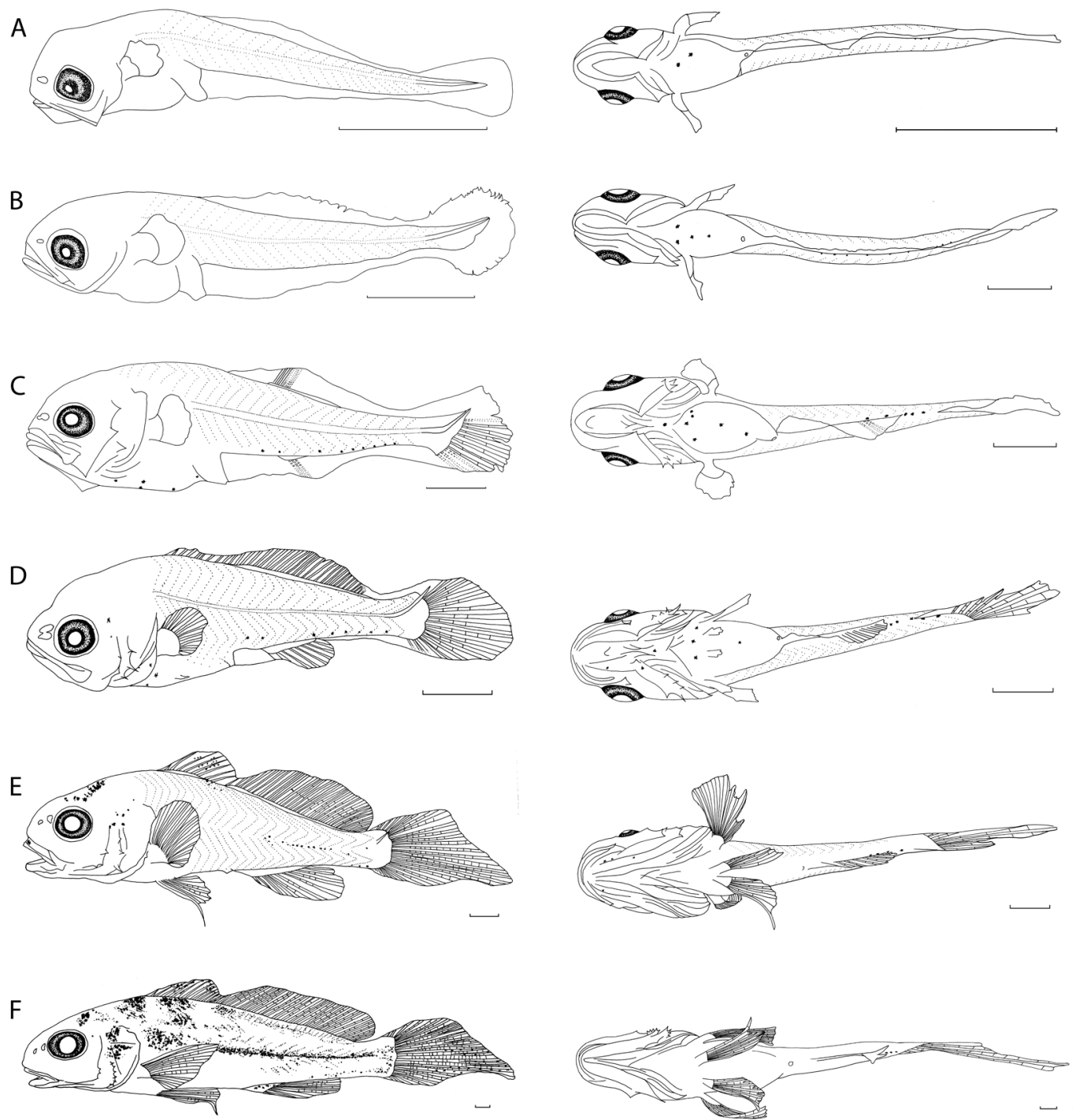

Fig. 1. Early development of Pachyurus bonariensis, ventral and lateral views. (A) preflexion (3.15 mm); (B) early flexion $(3.92 \mathrm{~mm})$; (C) late flexion $(5 \mathrm{~mm})$; (D) early postflexion $(6.71 \mathrm{~mm})$; (E) late postflexion $(11.57 \mathrm{~mm})$; and $(\mathbf{F})$ juvenile $(27.80 \mathrm{~mm})($ Scale: $1 \mathrm{~mm})$

fin length ( $35.8 \%$ to $43.6 \%$ ), and snout-anal fin length $(43.6 \%$ to $73.6 \%)$ increased during the larval period (Table 1).

Pigmentation: Initially, the pigmentation of the larvae consisted of dark and external dendritic chromatophores present in the ventral abdominal cavity. On the caudal peduncle, starting at $3.05 \mathrm{~mm}$, some internal chromatophores appeared in the ventral area, became more evident at $4.75 \mathrm{~mm}$. Pigmentation intensified throughout development, mostly in the ventral region. In postflexion stage, chromatophores appeared in the dorsal region of the head and at the base of the dorsal fin.

Fin development: In preflexion stage, the pectoral fin buds were present, but without 
TABLE 1

Minimum (Min), maximum (Max), mean (X) and standard deviation (SD) values for the length (mm) of the morphometric and meristic variables obtained for the larvae and juvenile Pachyurus bonariensis

\begin{tabular}{|c|c|c|c|c|c|c|c|c|}
\hline \multirow{3}{*}{$\begin{array}{l}\text { Variables } \\
\text { (mm) }\end{array}$} & \multicolumn{6}{|c|}{ Larval period } & \multirow{2}{*}{\multicolumn{2}{|c|}{$\begin{array}{l}\text { Juvenil period } \\
\qquad \mathrm{J}(\mathrm{n}=20)\end{array}$}} \\
\hline & \multicolumn{2}{|c|}{$P F(n=20)$} & \multicolumn{2}{|c|}{ FL $(n=20)$} & \multicolumn{2}{|c|}{$\mathrm{FP}(\mathrm{n}=20)$} & & \\
\hline & Min/Max & $\mathrm{X} \pm \mathrm{SD}$ & Min/Max & $\mathrm{X} \pm \mathrm{SD}$ & $\operatorname{Min} / \operatorname{Max}$ & $\mathrm{X} \pm \mathrm{SD}$ & $\operatorname{Min} / \operatorname{Max}$ & $\mathrm{X} \pm \mathrm{SD}$ \\
\hline SL & $2.30-4.75$ & $3.41 \pm 0.61$ & $3.92-6.33$ & $5.25 \pm 0.74$ & $6.71-11.71$ & $9.16 \pm 1.63$ & $17.90-34.55$ & $25.16 \pm 4.63$ \\
\hline HD & $0.50-1.00$ & $0.72 \pm 0.15$ & $0.75-1.92$ & $1.38 \pm 0.34$ & $2.00-3.57$ & $2.64 \pm 0.45$ & $4.14-6.86$ & $5.51 \pm 0.80$ \\
\hline HL & $0.50-1.20$ & $0.76 \pm 0.18$ & $1.00-2.25$ & $1.55 \pm 0.42$ & $2.43-4.14$ & $3.18 \pm 0.59$ & $5.57-11.14$ & $8.10 \pm 1.30$ \\
\hline $\mathrm{SnL}$ & $0.15-0.35$ & $0.22 \pm 0.05$ & $0.25-0.71$ & $0.43 \pm 0.12$ & $0.57-1.29$ & $0.88 \pm 0.21$ & $1.57-2.86$ & $2.11 \pm 0.38$ \\
\hline $\mathrm{JL}$ & $0.28-0.50$ & $0.39 \pm 0.08$ & $0.44-1.12$ & $0.71 \pm 0.22$ & $1.00-2.00$ & $1.45 \pm 0.27$ & $1.71-3.00$ & $2.49 \pm 0.44$ \\
\hline ED & $0.18-0.35$ & $0.26 \pm 0.04$ & $0.25-0.58$ & $0.42 \pm 0.11$ & $0.57-1.14$ & $0.85 \pm 0.15$ & $1.86-3.29$ & $2.38 \pm 0.39$ \\
\hline $\mathrm{BD}$ & $0.55-1.25$ & $0.80 \pm 0.18$ & $0.92-2.17$ & $1.52 \pm 0.37$ & $2.29-4.00$ & $2.90 \pm 0.48$ & $4.57-8.86$ & $6.51 \pm 1.16$ \\
\hline $\mathrm{SnP}$ & $0.55-1.25$ & $0.83 \pm 0.19$ & $1.00-2.25$ & $1.56 \pm 0.43$ & $2.43-4.29$ & $3.28 \pm 0.62$ & $5.71-11.43$ & $8.04 \pm 1.59$ \\
\hline $\mathrm{SnV}$ & - & - & - & - & $2.29-4.57$ & $3.46 \pm 0.68$ & $6.00-13.57$ & $8.91 \pm 1.88$ \\
\hline $\mathrm{SnD}$ & - & - & - & - & $2.71-4.71$ & $3.66 \pm 0.68$ & $6.00-12.00$ & $8.35 \pm 1.61$ \\
\hline $\mathrm{SnA}$ & - & - & - & - & $3.14-7.43$ & $5.62 \pm 1.28$ & $9.29-23.00$ & $15.07 \pm 3.37$ \\
\hline \multicolumn{9}{|c|}{ Relations (\%) } \\
\hline $\mathrm{HD} / \mathrm{HL}$ & $80.00-107.7$ & $95.41 \pm 7.63$ & $75.00-108.0$ & $89.66 \pm 8.93$ & $71.50-96.23$ & $82.32 \pm 5.71$ & $57.74-74.55$ & $68.35 \pm 4.57$ \\
\hline $\mathrm{SnL} / \mathrm{HL}$ & $23.08-35.71$ & $29.42 \pm 4.37$ & $20.89-35.21$ & $28.11 \pm 3.72$ & $21.33-36.31$ & $27.22 \pm 3.86$ & $21.13-33.39$ & $26.10 \pm 2.46$ \\
\hline ED/HL & $29.17-41.67$ & $34.53 \pm 4.46$ & $20.89-33.60$ & $27.16 \pm 3.80$ & $22.80-31.85$ & $26.67 \pm 2.27$ & $26.42-33.39$ & $29.41 \pm 1.78$ \\
\hline JL/HL & $32.35-75.0$ & $43.13 \pm 10.1$ & $33.80-58.33$ & $46.76 \pm 5.93$ & $33.30-55.56$ & $46.40 \pm 6.42$ & $23.44-35.01$ & $30.83 \pm 3.67$ \\
\hline $\mathrm{HL} / \mathrm{SL}$ & $19.05-25.26$ & $21.98 \pm 1.69$ & $22.22-35.69$ & $29.16 \pm 4.44$ & $31.68-38.43$ & $35.11 \pm 2.64$ & $29.37-39.73$ & $32.43 \pm 2.84$ \\
\hline $\mathrm{BD} / \mathrm{SL}$ & $20.63-29.41$ & $23.40 \pm 2.11$ & $23.47-34.28$ & $28.57 \pm 3.75$ & $27.62-34.16$ & $31.78 \pm 1.72$ & $23.72-30.25$ & $25.92 \pm 1.46$ \\
\hline $\mathrm{SnP} / \mathrm{SL}$ & $20.63-27.06$ & $24.26 \pm 1.48$ & $20.12-35.69$ & $29.37 \pm 4.77$ & $29.45-38.43$ & $35.78 \pm 2.14$ & $25.32-40.29$ & $32.00 \pm 2.76$ \\
\hline $\mathrm{SnV} / \mathrm{SL}$ & - & - & - & - & $32.29-42.08$ & $37.74 \pm 2.35$ & $31.67-43.28$ & $35.35 \pm 2.69$ \\
\hline $\mathrm{SnD} / \mathrm{SL}$ & - & - & - & - & $35.80-43.57$ & $39.98 \pm 2.14$ & $30.25-40.29$ & $33.19 \pm 2.14$ \\
\hline $\mathrm{SnA} / \mathrm{SL}$ & - & - & - & - & $43.64-73.58$ & $61.17 \pm 7.93$ & $35.06-75.27$ & $59.95 \pm 7.50$ \\
\hline \multicolumn{9}{|l|}{ Myomeres } \\
\hline Total & $22-26$ & $25 \pm 1$ & $24-28$ & $25 \pm 1$ & $24-26$ & $25 \pm 0$ & - & - \\
\hline Preanal & $7-11$ & $9 \pm 1$ & $8-12$ & $10 \pm 1$ & $11-14$ & $13 \pm 1$ & - & - \\
\hline Postanal & $13-18$ & $16 \pm 1$ & $14-17$ & $16 \pm 1$ & $11-14$ & $12 \pm 1$ & - & - \\
\hline \multicolumn{9}{|l|}{ Rays } \\
\hline $\mathrm{P}$ & - & - & - & - & $14-17$ & $16 \pm 1$ & $15-17$ & $17 \pm 0.66$ \\
\hline $\mathrm{V}$ & - & - & - & - & 5 & 5 & 5 & 5 \\
\hline $\mathrm{D}$ & - & - & - & - & $28-36$ & $31 \pm 2$ & $29-32$ & $30 \pm 0.97$ \\
\hline $\mathrm{A}$ & - & - & - & - & 6 & 6 & 6 & 6 \\
\hline
\end{tabular}

$\mathbf{n}=$ number of individuals analyzed, $\mathbf{P F}=$ preflexion, $\mathbf{F L}=$ flexion, $\mathbf{F P}=$ postflexion, $\mathbf{J}=$ juveniles, $\mathbf{S L}=$ standard length, $\mathbf{H D}=$ head depth, $\mathbf{H L}=$ head length, $\mathbf{S n L}=$ snout length, $\mathbf{E D}=$ eye diameter, $\mathbf{J L}=$ jaw length, $\mathbf{B D}=$ body depth, $\mathbf{S n P}=$ snoutpectoral fin length, $\mathbf{S n V}=$ snout-pelvic fin length, $\mathbf{S n D}=$ snout-dorsal fin length, $\mathbf{S n A}=$ snout-anal fin length, $\mathbf{P}=$ pectoral fin, $\mathbf{V}=$ pelvic fin, $\mathbf{D}=$ dorsal fin, $\mathbf{A}=$ anal fin. Missing measurements are because of incompletely developed larvae.

rays. The first rays of the caudal fin appeared at approximately $5.00 \mathrm{~mm}$, and their segmentation occurred at $5.42 \mathrm{~mm}$, when the bud of the pelvic fin also appeared. In late flexion stage, the first rays of the anal $(5.42 \mathrm{~mm})$, pectoral
$(5.67 \mathrm{~mm})$ and dorsal $(5.33 \mathrm{~mm})$ fins were formed, the last of which exhibits two distinct regions: the first was formed only by spines, and the second, which comprises over half of the fin, was formed by rays. The anal fin also 
has spines, but without any differentiation. The first rays of the pelvic fin were formed at approximately $7.57 \mathrm{~mm}$. At this length, the caudal, dorsal and anal fins display segmented rays. The fin development sequence (regarding the appearance of the first rays) and the number of rays in this period were as follows: caudal, dorsal (28-36), anal (six), pectoral (14-17) and pelvic (five). In late postflexion stage, the segmentation of the pectoral fin rays began.

Juvenile period (Fig. 1F; Table 1): The individuals exhibited a standard length ranging from 17.90 to $34.50 \mathrm{~mm}$. The eyes were ellipti$\mathrm{cal}$, and the mouth remained sub-terminal. The scales were fully formed and cover the entire body. The myomeres were no longer visible in this period. The variables head length $(29.4$ $\%$ to $39.7 \%$ ), head depth ( $57.7 \%$ to $74.5 \%$ ), snout length ( $21.1 \%$ to $33.4 \%$ ), eye diameter (26.4\% to $33.4 \%)$, body depth (23.7\% to $30.2 \%)$, and snout-pectoral fin length (25.3 $\%$ to $40.3 \%$ ), snout-dorsal fin length (30.2\% to $40.3 \%$ ), and snout-anal fin length (35.1\% to $75.3 \%$ ) decreased throughout development, whereas the snout-pelvic fin length $(31.7 \%$ to $43.3 \%$ ) increased (Table 1).

Pigmentation: Pigmentation became more evident at this period, with the chromatophores being concentrated in the dorsal region and on the opercle, near the eyes. Along the body, the chromatophores were aligned with the median groove, which was formed by the merging of myomeres, and were present at the bases of the dorsal and caudal fins.

Fin formation: The complete formation of the rays of all fins, including their segmentation, occurred in this period. The complete fin development sequence and the total number of the spines and rays of the fins were as follows: caudal, dorsal (XI+29-32), anal (II+six), pelvic (I+five) and pectoral (15-17).

\section{Plagioscion ternetzi}

Larval period (Fig. 2A, Fig. 2B, Fig. 2C, Fig. 2D, Fig. 2E; Table 2): The analyzed individuals exhibited a standard length ranging from 2.60 to $13.14 \mathrm{~mm}$. Their body length ranged from moderate to long $(18.0 \%$ to $35.8 \%$ ) and their head length from small to large $(17.5 \%$ to $40.1 \%)$. The yolk sac was completely absorbed starting at $3.15 \mathrm{~mm}$. The finfold was hyaline, remains until postflexion stage and was totally absorbed at $7.57 \mathrm{~mm}$. The intestine was initially short and roughly triangular but became long in postflexion larvae, extending beyond the middle of the body. The mouth was terminal, and the nostril became double at $11.00 \mathrm{~mm}$. The eyes were spherical and well pigmented throughout development. Eye diameter ranged from small to large (13.3 $\%$ to $41.8 \%$ ). The opercle was fully formed at $3.35 \mathrm{~mm}$, and spines preopercular (three internal and four external) appeared in flexion larvae. In preflexion stage, the gas bladder was inflated; the notochord was uninflected; and both structures were visible in transparency. In the flexion stage, the notochord was flexed such that the hypural bones may be observed. At approximately $8.14 \mathrm{~mm}$, the swim bladder and the notochord were no longer visible in transparency. The lateral line started to became clearly curvilinear at $4.70 \mathrm{~mm}$. Scales began to appear at $10.71 \mathrm{~mm}$ and were concentrated at the caudal peduncle. The total number of myomeres ranged from 23 to 26 throughout larval development. However, there was a change in the number of pre and postanal myomeres between the stages of development. The number of preanal myomeres increased from eight to nine in preflexion, from nine to 11 in flexion, and from 12 to 15 in postflexion. The number of postanal myomeres ranged from 15 to 16 in preflexion, from 13 to 16 in flexion and from 11 to 12 in postflexion (Table 2).

The variables snout length (18.7\% to 40 $\%$ ) and head depth (60\% to $110 \%$ ) decreased during the developmental period. However, snout-pectoral fin length ( $18.4 \%$ to $40.1 \%)$, snout-dorsal fin length (31.1\% to $41.3 \%)$, and snout-anal fin length (57.6 \% to $65.2 \%)$ increased (Table 2). The total number of myomeres ranged from 24 to 26 (8-13 preanal and 12-17 postanal). 
A

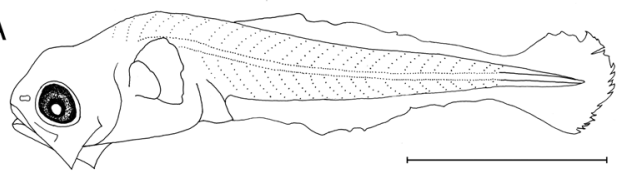

B

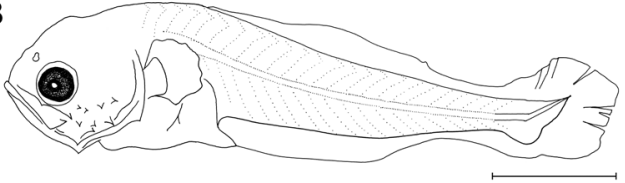

C
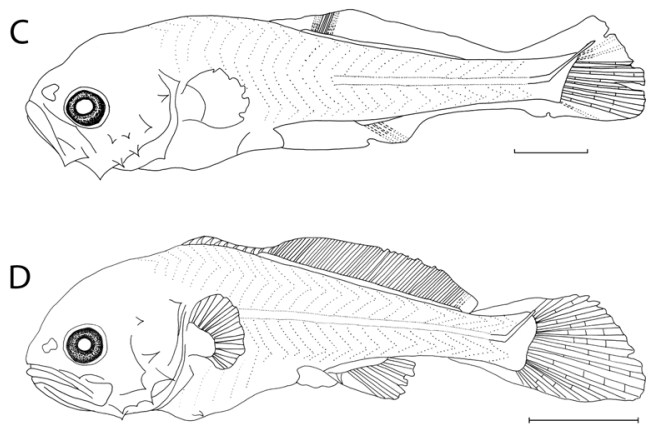

$\mathrm{E}$

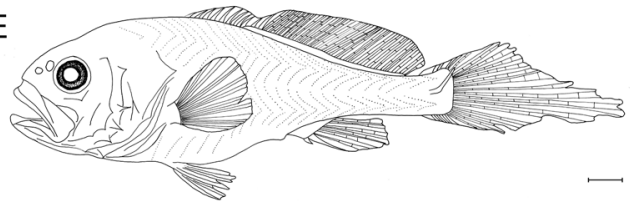

$\mathrm{F}$

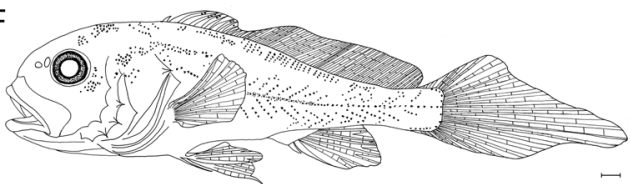

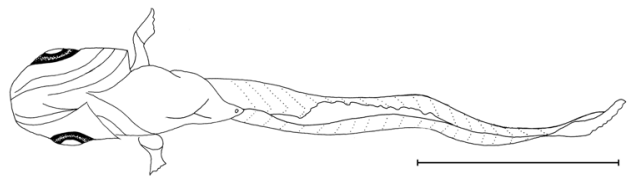
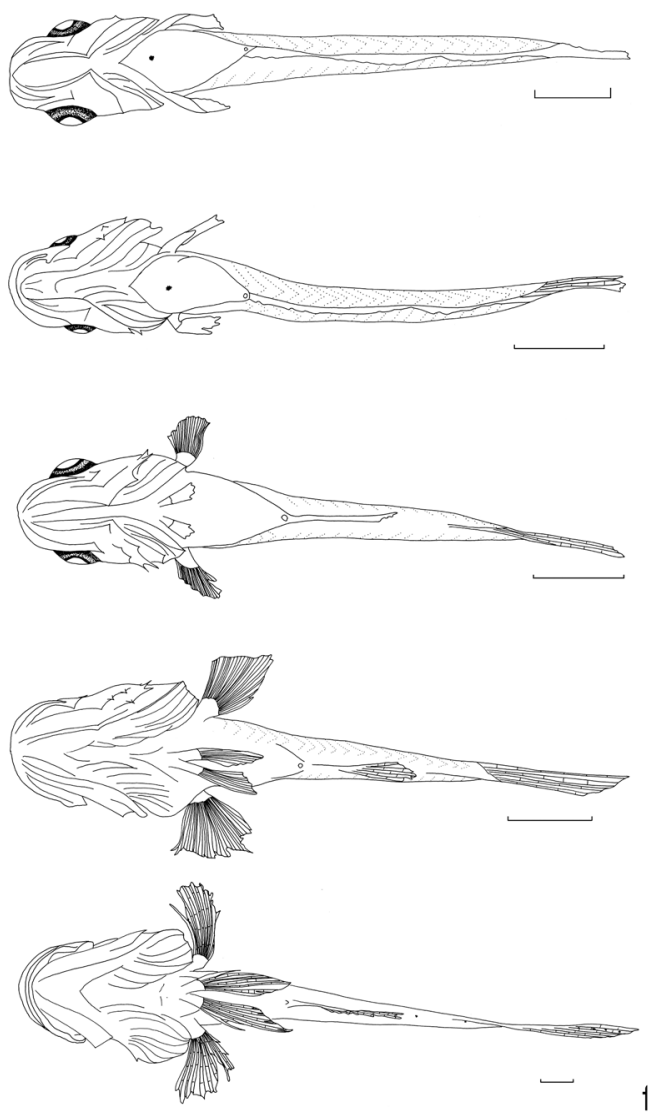

Fig. 2. Early development of Plagioscion ternetzi, ventral and lateral views. (A) preflexion (2.85 mm); (B) early flexion $(4.70 \mathrm{~mm})$; (C) late flexion $(5.5 \mathrm{~mm})$; (D) early postflexion $(6.43 \mathrm{~mm}) ;(\mathbf{E})$ late postflexion $(10.71 \mathrm{~mm})$; and $(\mathbf{F})$ juvenile $(20 \mathrm{~mm})($ Scale: $1 \mathrm{~mm})$.

Pigmentation: Most larvae were not pigmented, but in those that were, the pigmentation consisted of small numbers of dark dendritic chromatophores located in the ventral region of the abdominal cavity. Pigmentation only became evident in late postflexion stage, when some chromatophores were observed on the top of the head.
Fin formation: The buds of the pectoral fin were observed in preflexion stage. The first caudal rays appeared starting at $5.20 \mathrm{~mm}$, and segmentation was first observed at $5.71 \mathrm{~mm}$; at this length, the buds of the pelvic fin appeared, and the rays of the pectoral, dorsal and anal fins were formed. In postflexion stage, at 7.57 $\mathrm{mm}$, the segmentation of the dorsal and anal 
TABLE 2

Minimum (Min), maximum (Max), mean (X) and standard deviation (SD) values for the length (mm) of the morphometric and meristic variables obtained for the larvae and juvenile Plagioscion ternetzi

\begin{tabular}{|c|c|c|c|c|c|c|c|c|}
\hline \multirow{3}{*}{$\begin{array}{c}\text { Variables } \\
(\mathrm{mm})\end{array}$} & \multicolumn{6}{|c|}{ Larval period } & \multirow{2}{*}{\multicolumn{2}{|c|}{$\begin{array}{c}\text { Juvenile period } \\
\qquad J(n=20)\end{array}$}} \\
\hline & \multicolumn{2}{|c|}{$\mathrm{PF}(\mathrm{n}=20)$} & \multicolumn{2}{|c|}{ FL $(n=20)$} & \multicolumn{2}{|c|}{$\mathrm{FP}(\mathrm{n}=20)$} & & \\
\hline & $\operatorname{Min} / \operatorname{Max}$ & $\mathrm{X} \pm \mathrm{SD}$ & Min/Max & $\mathrm{X} \pm \mathrm{SD}$ & $\operatorname{Min} / \operatorname{Max}$ & $\mathrm{X} \pm \mathrm{SD}$ & Min/Max & $\mathrm{X} \pm \mathrm{SD}$ \\
\hline SL & $2.60-4.00$ & $3.20 \pm 0.40$ & $3.40-5.80$ & $4.64 \pm 0.66$ & $5.71-13.14$ & $8.72 \pm 2.28$ & $13.57-33.20$ & $17.77 \pm 5.14$ \\
\hline HD & $0.40-1.07$ & $0.62 \pm 0.14$ & $0.70-1.50$ & $1.07 \pm 0.26$ & $1.57-3.86$ & $2.49 \pm 0.71$ & $3.57-9.14$ & $4.87 \pm 1.29$ \\
\hline HL & $0.50-1.20$ & $0.67 \pm 0.16$ & $0.70-1.80$ & $1.21 \pm 0.29$ & $1.86-4.86$ & $3.11 \pm 0.93$ & $4.71-10.71$ & $6.27 \pm 1.57$ \\
\hline $\mathrm{SnL}$ & $0.15-0.40$ & $0.20 \pm 0.06$ & $0.15-0.60$ & $0.34 \pm 0.10$ & $0.43-1.43$ & $0.83 \pm 0.29$ & $1.14-3.00$ & $1.70 \pm 0.46$ \\
\hline JL & $0.20-0.45$ & $0.33 \pm 0.08$ & $0.25-0.88$ & $0.62 \pm 0.16$ & $0.88-2.56$ & $1.59 \pm 0.40$ & $2.50-5.80$ & $3.19 \pm 0.95$ \\
\hline ED & $0.15-0.33$ & $0.20 \pm 0.04$ & $0.20-0.40$ & $0.30 \pm 0.06$ & $0.43-1.14$ & $0.66 \pm 0.22$ & $1.14-2.86$ & $1.49 \pm 0.39$ \\
\hline $\mathrm{BD}$ & $0.55-1.33$ & $0.72 \pm 0.19$ & $0.70-1.70$ & $1.20 \pm 0.28$ & $1.71-4.29$ & $2.88 \pm 0.72$ & $4.29-12.57$ & $5.84 \pm 2.13$ \\
\hline $\mathrm{SnP}$ & $0.55-1.13$ & $0.74 \pm 0.15$ & $0.70-1.90$ & $1.21 \pm 0.31$ & $1.86-5.00$ & $3.18 \pm 0.96$ & $5.00-10.60$ & $6.54 \pm 1.46$ \\
\hline $\mathrm{SnV}$ & - & - & - & - & $2.14-5.29$ & $3.04 \pm 0.91$ & $5.00-10.45$ & $6.59 \pm 1.40$ \\
\hline $\operatorname{Sn} \mathrm{A}$ & - & - & - & - & $2.00-5.43$ & $3.28 \pm 0.94$ & $4.86-10.90$ & $6.42 \pm 1.52$ \\
\hline $\mathrm{SnD}$ & - & - & - & - & $3.29-8.57$ & $5.45 \pm 1.57$ & $8.86-17.43$ & $10.94 \pm 1.82$ \\
\hline \multicolumn{9}{|c|}{ Relations (\%) } \\
\hline $\mathrm{HD} / \mathrm{HL}$ & 78.57-109.09 & $93.20 \pm 9.13$ & $60.00-110.00$ & $89.56 \pm 10.51$ & $68.07-96.11$ & $80.63 \pm 6.63$ & $57.74-95.17$ & $77.38 \pm 7.91$ \\
\hline $\mathrm{SnL} / \mathrm{HL}$ & $18.75-40.00$ & $29.97 \pm 5.10$ & $20.00-40.00$ & $28.22 \pm 4.96$ & $22.38-33.24$ & $26.39 \pm 2.74$ & $19.25-32.33$ & $27.18 \pm 3.35$ \\
\hline ED/HL & $23.08-41.82$ & $29.91 \pm 5.10$ & $13.33-35.71$ & $25.28 \pm 4.96$ & $18.15-26.88$ & $21.13 \pm 2.35$ & $17.36-28.60$ & $23.83 \pm 2.57$ \\
\hline JL/HL & $30.77-64.29$ & $50.93 \pm 10.59$ & $35.71-62.50$ & $51.89 \pm 6.59$ & $38.22-62.26$ & $53.02 \pm 5.99$ & $33.65-55.20$ & $49.02 \pm 1.57$ \\
\hline $\mathrm{HL} / \mathrm{SL}$ & $17.54-34.58$ & $20.85 \pm 3.60$ & 19.51-35.71 & $25.71 \pm 3.73$ & $29.57-40.06$ & $35.34 \pm 2.42$ & $27.55-45.22$ & $35.68 \pm 3.50$ \\
\hline $\mathrm{BD} / \mathrm{SL}$ & $18.03-28.95$ & $22.47 \pm 4.44$ & $19.51-30.91$ & $25.58 \pm 2.85$ & $27.19-35.80$ & $33.13 \pm 2.28$ & $26.55-56.39$ & $32.52 \pm 6.49$ \\
\hline $\mathrm{SnP} / \mathrm{SL}$ & $19.30-32.56$ & $23.09 \pm 3.00$ & $18.42-32.76$ & $25.6 . \pm 3.22$ & $31.80-40.06$ & $36.12 \pm 2.30$ & $28.85-46.93$ & $37.41 \pm 3.87$ \\
\hline $\mathrm{SnV} / \mathrm{SL}$ & - & - & - & - & $29.13-40.26$ & $34.65 \pm 2.66$ & $28.22-46.67$ & $37.81 \pm 4.69$ \\
\hline $\mathrm{SnD} / \mathrm{SL}$ & - & - & - & - & $31.10-41.32$ & $37.43 \pm 2.65$ & $27.55-45.22$ & $36.61 \pm 3.84$ \\
\hline $\mathrm{SnA} / \mathrm{SL}$ & - & - & - & - & $57.62-65.22$ & $62.11 \pm 2.05$ & $34.94-70.90$ & $63.41 \pm 7.83$ \\
\hline \multicolumn{9}{|l|}{ Myomeres } \\
\hline Total & $23-25$ & $24.18 \pm 0.53$ & $23-26$ & $24.30 \pm 0.80$ & $24-26$ & $25.33 \pm 0.59$ & - & - \\
\hline Preanal & $8-9$ & $8.61 \pm 0.50$ & $9-11$ & $9.70 \pm 0.66$ & $12-15$ & $13.79 \pm 0.98$ & - & - \\
\hline Postanal & $15-16$ & $15.53 \pm 0.51$ & $13-16$ & $14.60 \pm 1.05$ & $11-12$ & $11.61 \pm 0.50$ & - & - \\
\hline \multicolumn{9}{|l|}{ Rays } \\
\hline $\mathrm{P}$ & - & - & - & - & $14-18$ & $16 \pm 1.51$ & $16-18$ & $17 \pm 0.75$ \\
\hline V & - & - & - & - & 5 & 5 & 5 & 5 \\
\hline $\mathrm{D}$ & - & - & - & - & $28-39$ & $35 \pm 2.48$ & $30-36$ & $35 \pm 1.62$ \\
\hline $\mathrm{A}$ & - & - & - & - & 6 & 6 & 6 & 6 \\
\hline
\end{tabular}

$\mathbf{n}=$ number of individuals analyzed, $\mathbf{P F}=$ preflexion, $\mathbf{F L}=$ flexion, $\mathbf{F P}=$ postflexion, $\mathbf{J}=$ juveniles, $\mathbf{S L}=$ standard length, $\mathbf{H D}=$ head depth, $\mathbf{H L}=$ head length, $\mathbf{S n L}=$ snout length, $\mathbf{E D}=$ eye diameter, $\mathbf{J L}=$ jaw length, $\mathbf{B D}=$ body depth, $\mathbf{S n P}=$ snoutpectoral fin length, $\mathbf{S n V}=$ snout-pelvic fin length, $\mathbf{S n D}=$ snout-dorsal fin length, $\mathbf{S n A}=$ snout-anal fin length, $\mathbf{P}=$ pectoral fin, $\mathbf{V}=$ pelvic fin, $\mathbf{D}=$ dorsal fin, $\mathbf{A}=$ anal fin. Missing measurements are because of incompletely developed larvae.

fins occurred (but not of the pectoral fin). The pelvic fin exhibited segmented rays at 9.43 $\mathrm{mm}$. The fin development sequence (regarding the appearance of the first rays) and the number of rays in this period were as follows: caudal, dorsal (28-39), anal (six), pectoral (14-18) and pelvic (five).
Juvenile period (Fig. 2F; Table 2): In this period, individuals display a standard length ranging from 13.57 to $33.20 \mathrm{~mm}$. The mouth was terminal, and the eyes were spherical. The scales were fully formed and cover the entire body. The variables head length $(27.5 \%$ to $45.2 \%)$, head depth $(57.7 \%$ to $95.2 \%)$, snout 
length (19.2 \% to $32.3 \%$ ), eye diameter (17.4 $\%$ to $28.6 \%$ ), body depth $(26.5 \%$ to $56.4 \%)$ and snout-pectoral fin length $(28.8 \%$ to 46.9 $\%)$, snout-dorsal fin length $(27.5 \%$ to 45.2 $\%$ ), and snout-anal fin length (34.9\% to 70.9 $\%)$ decreased throughout development, while the snout-pelvic fin length ( $28.2 \%$ to $46.7 \%)$ increased (Table 2).

Pigmentation: The pigmentation intensifies in this period, and chromatophores were concentrated in the upper region of the head, on the opercle and near the mouth. Along the body, the chromatophores were distributed in an aligned manner along the lateral median groove and were present between the first spines of the dorsal fin.

Fin formation: All fins were formed, and complete ray segmentation occurred in this period. The sequence of segmentation and the number of fin spines and rays were as follows: caudal, dorsal (XI+30-36), anal (II+six), pelvic (I+five) and pectoral (16-18).

Morphometric relationships: The variables snout length, eye diameter, head height and maxillary length were significantly correlated with head length according to the analysis of covariance (ANCOVA, $\mathrm{p}<0.05$ ). However, eye diameter was the only significantly variable different between the two species (Fig. 3; Table 3, Table 4), being larger in P. bonariensis at all development stages (Fig. 3A).
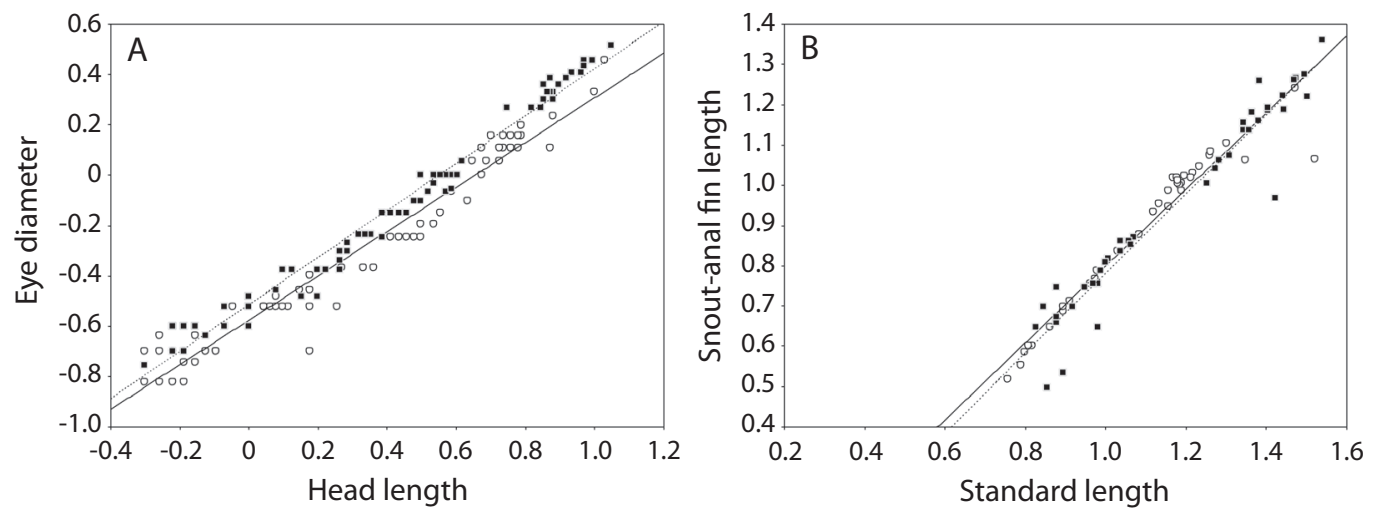

Fig. 3. Body ratios obtained for Pachyurus bonariensis (๘) and Plagioscion ternetzi ( $($ ) relative to head length: (A) eye diameter and body length: (B) snout-anal fin length. 
TABLE 3

Results of the analysis of covariance (ANCOVA) for the variables obtained in Pachyurus bonariensis (PB) and Plagioscion ternetzi (PT) individuals relative to head and standard length

\begin{tabular}{|c|c|c|c|c|c|c|c|c|c|}
\hline \multirow[t]{2}{*}{ Measured } & \multicolumn{2}{|c|}{ Intercept } & \multicolumn{2}{|c|}{$\begin{array}{c}\text { Covariable } \\
\text { Categorical (Species) }\end{array}$} & \multicolumn{2}{|c|}{$\begin{array}{c}\text { Covariable } \\
\text { Continuos }(\mathrm{CC})\end{array}$} & \multicolumn{2}{|c|}{$\begin{array}{l}\text { Covariable } \\
\text { Specie*CC }\end{array}$} & \multirow[t]{2}{*}{$\mathrm{R}^{2}$ multiple } \\
\hline & $\mathrm{F}$ & $p$ & F & $p$ & F & $p$ & $\mathrm{~F}$ & $p$ & \\
\hline $\mathrm{SnL} / \mathrm{HL}$ & 7458.93 & 0.000 & 0.11 & 0.745 & 5919.48 & 0.000 & 0.14 & 0.708 & 0.98 \\
\hline ED/HL & 6407.08 & 0.000 & 21.80 & 0.000 & 4626.78 & 0.000 & 3.92 & 0.055 & 0.97 \\
\hline $\mathrm{HD} / \mathrm{HL}$ & 96.76 & 0.000 & 4.37 & 0.038 & 12773.39 & 0.000 & 9.65 & 0.002 & 0.99 \\
\hline JL/HL & 5.35 & 0.023 & 16.10 & 0.000 & 3262.45 & 0.000 & 63.16 & 0.000 & 0.97 \\
\hline $\mathrm{HL} / \mathrm{SL}$ & 2274.74 & 0.000 & 12.55 & 0.001 & 5253.98 & 0.000 & 15.77 & 0.000 & 0.97 \\
\hline $\mathrm{BD} / \mathrm{SL}$ & 1966.99 & 0.000 & 21.21 & 0.000 & 4659.75 & 0.000 & 30.41 & 0.000 & 0.97 \\
\hline $\mathrm{SnP} / \mathrm{SL}$ & 2471.57 & 0.000 & 19.38 & 0.000 & 6098.13 & 0.000 & 25.96 & 0.000 & 0.98 \\
\hline $\mathrm{SnV} / \mathrm{SL}$ & 301.12 & 0.000 & 5.13 & 0.026 & 2049.83 & 0.000 & 4.71 & 0.033 & 0.97 \\
\hline $\mathrm{SnD} / \mathrm{SL}$ & 220.76 & 0.000 & 10.52 & 0.002 & 2305.39 & 0.000 & 10.13 & 0.002 & 0.97 \\
\hline $\mathrm{SnA} / \mathrm{SL}$ & 27.43 & 0.000 & 1.57 & 0.040 & 1035.74 & 0.000 & 0.30 & 0.585 & 0.94 \\
\hline
\end{tabular}

$\mathbf{S L}=$ standard length, $\mathbf{H D}=$ head depth, $\mathbf{H L}=$ head length, $\mathbf{S n L}=$ snout length, $\mathbf{E D}=$ eye diameter, $\mathbf{J L}=$ jaw length, $\mathbf{B D}=$ body depth, $\mathbf{S n P}=$ snout-pectoral fin length, $\mathbf{S n V}=$ snout-pelvic fin length, $\mathbf{S n D}=$ snout-dorsal fin length, $\mathbf{S n A}=$ snout-anal fin length. Significance level: $\mathrm{p}<0.05$ (log transformed data).

TABLE 4

Parameters of the linear regression analysis for the variables that differed significantly between Pachyurus bonariensis and Plagioscion ternetzi

\begin{tabular}{ccccccccc} 
Measured & Species & $a$ & $t$ & $p$ & $b$ & $t$ & $\mathrm{p}$ \\
\multirow{2}{*}{ ED } & PT & -0.576 & -56.90 & 0.000 & 0.884 & 41.95 & 0.000 \\
& PB & -0.513 & -57.60 & 0.000 & 0.937 & 56.38 & 0.000 \\
\multirow{2}{*}{ SnA } & PT & -0.154 & -3.49 & 0.001 & 0.953 & 23.72 & 0.000 \\
& PB & -0.205 & -4.04 & 0.000 & 0.986 & 23.22 & 0.000 \\
\hline
\end{tabular}

$\mathbf{E D}=$ eye diameter, $\mathbf{S n} \mathbf{A}=$ snout-anal fin length, $\mathbf{P B}=$ Pachyurus bonariensis, $\mathbf{P T}=$ Plagioscion ternetzi. Significance level: $\mathrm{p}<0.05$ (log transformed data).

critical, as the larvae need to find proper food for their survival before completely consuming all of their endogenous reserves (Bialetzki, Sanches, Baumgartner, \& Nakatani, 1998; Kamler, 2008). Feeding flexibility during the time interval in which the larvae are in this phase may directly affect their growth and survival, especially in the terminal stage of yolk absorption (Bialetzki et al., 2001).

The foraging site and the types of prey exploited are directly related to larval morphology. This was clear for both species analyzed, especially regarding the position of the morphological structures of the mouth and eye diameter. Pachyurus bonariensis and
P. ternetzi are initially zooplanktivorous and obtain food resources directly in the water column (M. Santin, unpublished data, 2007). However, $P$. bonariensis explores the substrate throughout its development, and the young feed mainly on Chironomidae and Ephemeroptera larvae (Fugi, Hahn, Novakowski, \& Balassa, 2007). This shift in habitat and food resources is therefore favored by changes in mouth position (from terminal to sub-terminal in the postflexion stage). The maintenance of the terminal mouth in $P$. ternetzi suggested that there were no marked dietary changes throughout the development of this species, though there was a change in the prevalence 
of the items consumed; i.e., larvae of this species eat zooplankton throughout their development (M. Santin, unpublished data, 2007). The change in eating habits occurred in juveniles and adults, which became piscivorous (Corrêa, Petry, \& Hahn, 2009).

In comparison, $P$. bonariensis larvae and juveniles exhibited an eye diameter that was always larger than that of $P$. ternetzi. This characteristic is also associated with feeding habits (Strauss, 1984). Strauss (1984) studied cichlid eye morphology also reported larger sizes in zooplanktivorous species, followed by insectivorous species, with smaller sizes being recorded in piscivorous species.

Larval development is separated by morphological jumps during ontogeny, when rapid growth of one or more body parts occurs (Sagnes, Gaudin, \& Statzner, 1997). Pachyurus bonariensis and $P$. ternetzi larvae exhibited a significant increase in head length in early development. These changes are most likely due to cerebral development, which leads to the diversification of motor and sensory skills (Cavicchioli \& Leonhardt, 1993; Bialetzki et al., 1998), such as the development of vision (Khemis et al., 2013).

The presence of spines in the cephalic region in both species is an overriding characteristic among the sciaenids (Johnson, 1984). This characteristic is useful for interspecific differentiation and may also be employed to distinguish sciaenid larvae from the larvae of other orders found in the freshwater environment, such as Characiformes, Siluriformes and Clupeiformes, and even from other Perciformes (e.g., Cichlidae, in which these spines are minimized) (W. Severi, unpublished data, 1997).

The finfold was observed to be the first fin to appear. The finfold supports the formation of the odd fins and acts as a propeller for locomotion and orientation (Webb \& Weihs, 1986). The bud of the pectoral fin was detected in the smaller larvae analyzed, and it is therefore likely that the larvae already hatch with the bud of the pectoral fin present and that ray formation occurs throughout ontogeny. The sequence of the formation of the fin rays (caudal, dorsal, anal, pelvic and pectoral) was observed in both $P$. bonariensis and P. ternetzi and has been recorded in Plagioscion squamosissimus (Nakatani et al., 1997). This sequence follows the pattern proposed by Johnson (1984) for the suborder Percoidei, which includes the family Sciaenidae.

For $P$. bonariensis, the body proportions head length and position of the pectoral fin increased while insertion of dorsal, anal and pelvic fins decreased. The same was observed for $P$. ternetzi, except for the insertion of the pelvic fin, which increased. Thus, unequal (or differentiated) growth during the ontogenetic development of these species is suggested. The changes in functional development and, consequently, in body shape are particularly striking during the first days of life and may lead to the formation of allometric growth patterns (Kupren et al., 2014). According to Huysentruyt, Moerkerke, Devaere and Adriaens (2009), the sequence of these allometric changes may be chronologically related to important early life history events, and therefore reflect an evolutionary ontogenetic response to functional requirements, such as feeding and locomotion.

The observed morphological development patterns were similar for the larvae and juveniles of $P$. bonariensis and $P$. ternetzi. However, the following characteristics (especially during the larval period) enable the discrimination of the two species:

(a) Pigmentation: Pachyurus bonariensis exhibited the greatest number of pigments, and as early as the preflexion stage, pigmentation was observed in the abdominal region and internal chromatophores occurred in the ventral region of the caudal peduncle. Pigmentation intensified throughout development.

(b) Mouth position: The mouth was in a terminal position throughout the larval development of $P$. ternetzi and shifts from a terminal to a sub-terminal position at the postflexion stage in P. bonariensis. 
(c) Eye shape: The eyes of $P$. ternetzi were spherical throughout development, while the eyes of $P$. bonariensis were initially spherical and became elliptical in postflexion stage.

(d) Cephalic spines: Pachyurus bonariensis had two internal and four external spines preopercular, while P. ternetzi exhibited three internal and four external spines.

(e) Snout-anal fin length: This distance was greater during the larval period in P. terne$t z i$. In the juvenile period, this pattern was reversed, and the length became greater for $P$. bonariensis in individuals larger than $34 \mathrm{~mm}$.

Despite the difficulty of intraspecific identification among fish larvae collected in natural environments, the morphological and morphometric tools used in the present study were effective in separating the early stages of development of the two morphologically similar species that share the same environment for reproduction.

\section{ACKNOWLEDGMENTS}

The authors would like to thank the PIBIC/ UEM and CNPq Programs for awarding study grants; FURNAS-Centrais Elétricas S/A for financing this research; Nupélia for logistic support; our friend Valmir Alves Teixeira for helping with the fieldwork; and colleagues in the Laboratory of Ichthyoplankton/Nupélia/ UEM for helping with the sample analysis. All experiments conducted in this work complied with the current laws of the country in which they were performed.

\section{RESUMEN}

Desarrollo temprano de dos especies de peces tropicales (Perciformes: Sciaenidae) en el Pantanal de Mato Grosso, Brasil. Las primeras fases del ciclo de vida no son conocidas lo suficiente para la mayoría de los peces de la región Neotropical. Así la descripción de larvas y juveniles de Pachyurus bonariensis y Plagioscion ternetzi, dos especies de corvinas que se encuentran en el Pantanal matogrossense, Brasil, fue realizada a través de cambios ontogénicos en la morfología externa, en la pigmentación y en el desarrollo de las aletas, al igual que en la morfometría y merística. El material fue recolectado en la bahía de Chacororé, río Cuiabá, entre marzo de 2000 y marzo 2004. Se analizaron 80 individuos de cada especie, siendo 60 larvas y 20 juveniles. Las larvas de $P$. bonariensis presentaron boca en posición terminal pasando a sub-terminal, ojos grandes, bien pigmentados y esféricos, tornándose pequeños y elípticos en post-flexión, espinas en el pre-opérculo (dos internas y cuatro externas); número total de miómeros variando entre 23 y 27 , pigmentación inicialmente escasa intensificándose, principalmente, en la región ventral; secuencia de formación y número total de espinas y radios de las aletas: caudal, dorsal (XI+29-32), anal (II+6), pélvica (I+5) y pectoral (15-17). Por otro lado, las larvas de $P$. ternetzi presentan una boca terminal: ojos grandes, bien pigmentado y esféricos, disminuyendo a medida que se desarrolla, espinas en el pre-opérculo (tres internas y cuatro externas); número total de miómeros variando entre 23 y 26; pigmentación inicialmente escasa, volviéndose evidente solo al final de la post-flexión, con la presencia de algunos cromatóforos en la región superior de la cabeza; secuencia de formación y número total de espinas y radios de las aletas: caudal, dorsal (XI+30-36), anal (II+6), pélvica (I+5) y pectoral (16-18). En la relación de las variables morfométricas, sólo la longitud de la aleta anal-hocico diferían entre las dos especies, siendo inicialmente mayor en $P$. ternetzi, mientras que sólo se hizo más grande en los jóvenes de $P$. bonariensis después de $34 \mathrm{~mm}$. A pesar de la dificultad de identificación intraespecífica entre larvas de peces recolectadas en ambientes naturales, las herramientas morfológicas y morfométricas utilizadas en el presente estudio fueron eficaces para la separación de las primeras etapas de desarrollo de las dos especies morfológicamente similares que comparten el mismo ambiente para la reproducción.

Palabras clave: corvinas, larvas, Pachyurus bonariensis, Plagioscion ternetzi, peces.

\section{REFERENCES}

Ahlstrom, E. H., \& Moser, H. G. (1976). Eggs and larvae of fishes and their role in systematic investigations and in fisheries. Revue des Travaux de L'institut des Peches Maritimes, 40, 285-402.

Ahlstrom, E. H., Butler, J. L., \& Sumida, B. Y. (1976). Pelagic stromateoid fishes (Pisces, Perciformes) of the Eastern Pacific: kinds, distributions, and early life histories and observations of five of these from the Northwest Atlantic. Bulletin of Marine Science, 26, 285-402.

Bialetzki, A., Sanches, P. V, Baumgartner, G., \& Nakatani, K. (1998). Caracterização morfológica e distribuição temporal de larvas e juvenis de Apareiodon affinis (Steindachner, 1879) (Osteichthyes, Parodontidae) no 
alto rio Paraná, Paraná. Revista Brasileira de Zoologia, 15, 1037-1047.

Bialetzki, A., Baumgartner, G., Sanches, P. V., Galuch, A. V., Luvisuto, M. A., Nakatani, K., Makrakis, M. C., \& Borges, M. E. E. (2001). Caracterização do desenvolvimento inicial de Auchenipterus osteomystax (Osteichthyes, Auchenipteridae) da bacia do rio Paraná, Brasil. Acta Scientiarum, 23, 377-382.

Bialetzki, A., Nakatani, K., Sanches, P. V., Baumgartner, G., \& Gomes, L. C. (2005). Larval fish assemblage in the Baía River (Mato Grosso do Sul State, Brazil): temporal and spatial patterns. Environmental Biology of Fishes, 73, 37-47.

Braga, F. M. S., \& Gomiero, L. M. (1997). Análise da pesca experimental realizada no reservatório de Volta Grande, rio Grande (MG/SP). Boletim do Instituto de Pesca, 24, 131-138.

Britski, H. A., Silimon, K. Z. de S., \& Lopes, B. S. (1999). Peixes do Pantanal: manual de identificação. Brasília, Embrapa.

Cassati, L. (2003). Family Sciaenidae (Drums or Croakers). In R. E. Reis, S. O. Kullander, \& C. J. Ferraris Jr. (Eds.), Check list of the freshwater fishes of South and Central America (pp. 599-602). Porto Alegre, Rio Grande do Sul: Edipucrs.

Cavicchioli, M., \& Leonhardt, J. H. (1993). Estudos do desenvolvimento morfológico de larvas de Curimbatá, Prochilodus scrofa (Steindachner, 1882), obtidas de reprodução induzida. Revista UNIMAR, 15, 109-124.

Corrêa, C. E., Petry, A. C., \& Hahn, N. S. (2009). Influência do ciclo hidrológico na dieta e estrutura trófica da ictiofauna do rio Cuiabá, Pantanal Mato-Grossense. Iheringia, Série Zoologia, 99, 456-463.

Fugi, R., Hahn, N. S., Novakowski, G. C., \& Balassa, G. C. (2007). Ecologia alimentar da corvina, Pachyurus bonariensis (Perciformes, Sciaenidae) em duas baías do Pantanal, Mato Grosso, Brasil. Iheringia, Série Zoologia, 97, 343-347.

Huysentruyt, F., Moerkerke, B., Devaere, S., \& Adriaens, D. (2009). Early development and allometric growth in the armoured catfish Corydoras aeneus (Gill, 1858). Hydrobiologia, 627, 45-54.

Johnson, G. D. (1984). Percoidei: development and relationships. In H. G. Moser, W. J. Richards, D. M. Cohen, M. P. Fahay, A. W. Kendall Jr., \& S. L. Richardson (Eds.), Ontogeny and systematics of fishes: based on International Symposium dedicated to the memory of Elbert Halvor Ahlstrom (pp. 464-498). Lawrence: American Society of Ichthyologists and Herpetologists (Special publication/American Society of Ichthyologists and Herpetologists, no. 1).
Kamler, E. (2008). Resource allocation in yolk-feeding fish. Reviews in Fish Biology and Fisheries, 18, 143-200.

Khemis, I. B., Gisbert, E., Alcaraz, C., Zoutein, D., Besbes, R., Zouiten, A., Masmoudi, A. S., \& Cahu, C. (2013). Allometric growth patterns and development in larvae and juveniles of thick-lipped grey mullet Chelon labrosus reared in mesocosm conditions. Aquaculture Research, 44, 1872-1888.

Kupren, K., Trabska, I., Zarski, D., Krejszeff, S., PalinskaZarska, K., \& Kucharczyk, D. (2014). Early development and allometric growth patterns in burbot Lota lota L. Aquaculture International, 22, 29-39.

Leis, J. M., \& Trnski, T. (1989). The larvae of Indo-Pacific shorefishes. Honolulu: University of Hawaii Press; Sidney: The Australian Museum.

Melo, A. J. S., \& Severi, W. (2010). Abundância e distribuição espacial e sazonal do ictioplâncton no reservatório de Sobradinho, rio São Francisco. In A. N. Moura, E. L. Araújo, M. C. Bitencourt-Oliveira, \& E. Pimentel (Eds.), Reservatórios do Nordeste do Brasil: biodiversidade, ecologia e manejo (pp. 503540). Recife, PE: Comunigraf.

Nascimento, S. F., Mello, A. H., Oliveira, G. F., Pereira, V. D. N., \& Mendes, A. S. (2011). Queda da produtividade de pescado no rio Tocantins: a percepção dos pescadores de marabá - Pará. Agroecossistemas, 3, 101-105.

Nakatani, K., Baumgartner, G., \& Baumgartner, M. S. T. (1997). Larval development of Plagioscion squamosissimus (Heckel) (Perciformes, Sciaenidae) of Itaipu reservoir (Paraná River, Brazil). Revista Brasileira de Zoologia, 14, 35-44.

Nakatani, K., Agostinho, A. A, Baumgartner, G., Bialetzki, A., Sanches, P. V., Makrakis, M. C., \& Pavanelli, C. S. (2001). Ovos e larvas de peixes de água doce: desenvolvimento e manual de identificação. Maringá: Eduem.

Nakatani, K., Bialetzki, A., Baumgartner, G., Sanches, P. V., \& Makrakis, M. C. (2004). Temporal and spatial dynamics of fish eggs and larvae. In S. M. Thomaz, A. A. Agostinho, \& N. S. Hahn (Eds.), The upper Paraná river and its floodplain: physical aspects, ecology and conservation (pp. 293-308). Leiden: Backhuys Publishers.

Nelson, J. S. (2006). Fishes of the world. New York: John Wiley \& Sons.

Oliveira, E. C., \& Ferreira, E. J. G. (2008). Spawning areas, dispersion and microhabitats of fish larvae in the Anavilhanas Ecological Station, rio Negro, Amazonas State, Brazil. Neotropical Ichthyology, 6, 559-566.

Sagnes, P., Gaudin, P., \& Statzner, B. (1997). Shifts in morphometrics and their relation to hydrodynamic 
potential and habitat use during grayling ontogenesis. Journal of Fish Biology, 50, 846-858.

Santos, N. B., Rocha, R. M., \& Fredou, F. L. (2010). Reproductive biology of Plagioscion magdalenae (Teleostei: Sciaenidae) (Steindachner, 1878) in the bay of Marajo, Amazon Estuary, Brazil. Neotropical Ichthyology, 8, 333-340.

Soares, C. L., \& Teixeira, G. E. (2012). Distribuição de ovos e larvas de peixes antes e depois do represamento. In R. Mazzoni, E. P. Caramaschi, \& R. IglesiasRio (Eds.), Usina Hidrelétrica de Serra da Mesa: 15 anos de estudo da ictiofauna do alto Tocantins (pp. 263-286). Rio de Janeiro: Furnas.

Strauss, R. E. (1984). Allometry and functional feeding morphology in haplochromine cichlids. In A. A. Echelle, \& I. Kornfield (Eds.), Evolution of fish species flocks (pp. 217-229). Orono: University of Maine Press.

Webb, P. W., \& Weish, D. (1986). Functional locomotor morphology of early life history stages of fishes. Transactions of the American Fisheries Society, 115, 115-127. 